\section{Intrathecal meperidine for elective Caesarean section: a comparison with lidocaine}

Sunil Kumar Kafle MB BS DA (TU)
The purpose of this study was to determine the efficacy of intrathecal meperidine in patients undergoing Caesarean section, and also to compare meperidine with heavy lidocaine. Fifty full-term pregnant women, ASA physical status I or II, presenting for elective Caesarean section under spinal anaesthesia were randomly divided into two groups with 25 in each, to receive either intrathecal meperidine or lidocaine. All patients received premedication with oral ranitidine, $150 \mathrm{mg}$, the night before surgery, and again two hours before surgery. Patients in the meperidine group were also given metoclopramide iv $10 \mathrm{mg}$ one hour before surgery. After iv $20 \mathrm{ml} \cdot \mathrm{kg}^{-1}$ Ringer's lactate, patients were given either $5 \%$ meperidine $1 \mathrm{mg} \cdot \mathrm{kg}^{-1}$ or $5 \%$ heavy lidocaine $1.2101 .4 \mathrm{ml}$ intrathecally. The sensory and motor blockades in all except two patients in each group who required sedation at the time of skin incision were adequate for surgery. None of the mothers suffered from any major side effects. The incidence of hypotension was higher in the lidocaine group than in meperidine group $(P<0.05)$. Pruritus and drowsiness were more common in meperidine group than in lidocaine group $(P<0.01)$. All the newborns in both groups cried immediately after birth and had an Apgar scope $>7$. The mean duration of postoperative analgesia was six hours in the meperidine group and one hour in the lidocaine group $(P<0.01)$. Postoperative analgesia requirement was less in the meperidine than in the lidocaine group $(P<0.01)$. It is concluded that intrathecal $5 \%$ meperidine in a dose of $1 \mathrm{mg} \cdot \mathrm{kg}^{-1}$ is superior to $5 \%$ heavy lidocaine because of the prolonged postoperative

\section{Key words}

ANALGESIA: postoperative;

ANALGESICS: meperidine;

ANAESTHESIA: obstetric;

ANAESTHETIC TECHNIQUES: spinal;

ANAESTHETICS, LOCAL: lidocaine, meperidine.

From the Department of Anaesthesiology, Institute of

Medicine, Tribhuvan University Teaching Hospital,

Kathmandu, Nepal.

Address correspondence to: Dr. S.K. Kafle, Associate

Professor of Anaesthesiology, Tribhuvan University Teaching

Hospital, P.O. Box 4585, Kathmandu, Nepal.

Accepted for publication 19th April, 1993. analgesia. The commercial 5\% solution of meperidine can be used, without addition, for this purpose.

L'objectif de cette étude eśt de déterminer l'efficacité de la mépéridine intrarachidienne chez les patients subissant une césarienne, ainsi que de comparer la mépéridine à la lidocaïne hyperbare. Cinquante patientes à terme, ASA l ou 2, programmées pour une césarienne sous anesthésie rachidienne ont été aléatoirement séparées en deux groupes de 25, pour recevoir en intrathécal, soit de la mépéridine, soit de la lidocaïne. Toutes les patientes ont reçu une prémédication de $150 \mathrm{mg}$ de ranitidine par voie orale, le soir ainsi que deux heures avant la chirurgie. Les patientes du groupe mépéridine ont aussi reçu $10 \mathrm{mg}$ de métoclopramide iv une heure avant la chirurgie. Après l'administration de $20 \mathrm{ml} \cdot \mathrm{kg}^{-1}$ iv de lactate Ringer, les patients ont reçu par voie intrarachidienne soit $1 \mathrm{mg} \cdot \mathrm{kg}^{-1}$ de mépéridine $5 \%$, soit 1,2 à $1,4 \mathrm{ml}$ de lidocaïne hyperbare $5 \%$. Les blocs sensitif et moteur ont été adéquats pour la chirurgie chez toutes les patientes sauf deux de chaque groupe qui ont nécessité une sédation au moment de lincision cutanée. Aucune n'a souffert d'effets secondaires majeurs. Lincidence de l'hypotension a été plus élevée dans le groupe lidocaïne que dans le groupe mépéridine $(P<0,05)$. Le prurit et la somnolence ont été plus habituels dans le groupe mépéridine que dans le groupe lidocaine $(P<0,01)$. Dans les deux groupes, tous les nouveauxnés ont crié immédiatement après la naissance et ont eu un score d'Apgar >7. La durée moyenne de l'analgésie postopératoire a été de six heures dans le groupe mépéridine et diune heure dans le groupe lidocaine $(P<0,01)$. Les besoins d'analgésie post-opératoire ont été moindre dans les groupes mépéridine que dans le groupe lidocaïne $(P<0,01)$. En conclusion, la mépéridine $5 \%$ donnée en intrarachidien a la dose de $1 \mathrm{mg} \cdot \mathrm{kg}^{-1}$ est supérieure à la lidocaïne hyperbare $5 \%$ par son analgésie post-opératoire prolongée. La solution commerciale de mépéridine à $5 \%$ sans additif peut-être utilisée pour cette indication.

Both epidural and intrathecal opioids are commonly used for postoperative pain control but meperidine is the only opioid which has been used to provide analgesia for the surgical procedure. However, there are only limited re- 
TABLE I Demographic data (mean \pm SD)

\begin{tabular}{lcc}
\hline & Meperidine group & Lidocaine group \\
\hline Age (yr) & $23.7 \pm 8.7$ & $23.2 \pm 8.0$ \\
Height (cm) & $155.0 \pm 5.2$ & $156.0 \pm 4.8$ \\
Weight (kg) & $51.6 \pm 7.0$ & $52.9 \pm 8.5$ \\
Gestational age (wk) & $38.6 \pm 1.2$ & $38.7 \pm 1.0$ \\
\hline
\end{tabular}

ports of its use as the sole agent in patients undergoing Caesarean section.' The present study was conducted to assess the efficacy and safety of spinal meperidine both in the mother and the newborn, and to compare its efficacy with $5 \%$ heavy spinal lidocaine.

\section{Methods}

Fifty full-term pregnant women of ASA status I or II, presenting for elective Caesarean section, were randomly divided into two groups ( $n=25$ each) to receive either intrathecal $5 \%$ meperidine $1 \mathrm{mg} \cdot \mathrm{kg}^{-1}(1-1.3 \mathrm{ml}$ depending on body weight) or $5 \%$ heavy lidocaine $1.2-1.4 \mathrm{ml}$. All patients received premedication with oral ranitidine $150 \mathrm{mg}$ the night before surgery, and two hours before operation on the day of surgery. Patients in the meperidine group were given metoclopramide $i v 10 \mathrm{mg}$ approximately one hour before surgery. All patients received $20 \mathrm{ml} \cdot \mathrm{kg}^{-1}$ Ringer's lactate solution $\dot{n}$ before the subarachnoid block was performed. Then, lumbar puncture was performed either at the $\mathrm{L}_{2-3}$ or $\mathrm{L}_{3-4}$ level with the patient in the lateral position. Patients were given either a preservative free solution of $5 \%$ meperidine, 1 $\mathrm{mg} \cdot \mathrm{kg}^{-1}$, or $5 \%$ heavy lidocaine, 1.2 to $1.4 \mathrm{ml}$, depending on their height and weight. The patients were then turned supine with left uterine displacement.

The levels of sensory and motor block were determined using pin-prick and the Bromage motor score before incision, and during surgery to assess the highest level of sensory block. The levels were measured until they had worn off. Intraoperative monitoring consisted of heart rate, blood pressure, respiration, and ECG. Patients were also asked if they had any difficulty in breathing. After the operation, the patients were observed in the recovery room until the motor and sensory blocks had disappeared.

Postoperative ward staffs were instructed to contact the anaesthetist on duty for management of any complications and sedation orders for $72 \mathrm{hr}$ postoperatively. Direct observation was the only method used to assess respiration. Patients who asked for sedation or analgesia were given meperidine $1 \mathrm{mg} \cdot \mathrm{kg}^{-1}$ im on demand, and the injection time was noted. The time from the administration of anaesthesia to the time when the patient first complained of pain was considered as the duration of postoperative analgesia. Neurological deficits were ruled out in all patients before discharge from the hospital. No baby was found to have any problems as reported by paediatrician.

Student's $\mathrm{t}$ test was used for comparing postoperative analgesia, and analgesic requirement, and the chi square test for comparing the incidence of complications between the two groups.

\section{Results}

The demographic data showed the two groups were similar with respect to age, height, weight and gestational age (Table I).

\section{Sensory blockade}

Onset of sensory blockade was five minutes (range 3-6 $\min$ ) in the lidocaine group, and seven minutes (range $5-8 \mathrm{~min}$ ) in the meperidine group. The final level of sensory blockade was $\mathrm{T}_{2}-\mathrm{T}_{4}$ in the lidocaine group, and $T_{4}-T_{6}$ in the meperidine group despite a similar degree of head-down tilt $\left(5-10^{\circ}\right)$. The sensory block lasted a mean of $60 \mathrm{~min}$ (range $55-70 \mathrm{~min}$ ) in the meperidine group and $50 \mathrm{~min}$ (range $45-60 \mathrm{~min}$ ) in the lidocaine group.

Two patients from each group required sedation with thiopentone, $75 \mathrm{mg}$, at the time of incision, as they were very apprehensive. The levels of sensory blockade were found to be adequate in both these patients.

\section{Motor blockade}

Motor blockade was complete in all patients in the lidocaine group and ranged between grades II and III in the meperidine group. However, abdominal muscular relaxation was adequate for surgery in the meperidine group and the surgeons could not differentiate between the two groups. The motor block lasted a mean of 50 $\mathrm{min}$ in the meperidine group, and $45 \mathrm{~min}$ in the lidocaine group.

\section{The newborn}

All newborns in both groups cried immediately after birth. Apgar score was $>7$ in all at birth and at five minutes. No baby was reported to have problems later on and at the time of discharge.

\section{Complications}

The intraoperative complications are as shown in Table II.

Hypotension (decrease in BP $>20 \%$ of baseline) occurred in eight patients in the meperidine group and in 15 patients in the lidocaine group $(P<0.05)$.

Pruritus of the shoulder, neck and face was observed in eight patients in the meperidine group and none in the lidocaine group $(P<0.01)$.

Patients in the meperidine group were drowsy but readily arousable without added sedation. In the lidocaine group only patients who received intraoperative sedation 
TABLE II Intraoperative complications

\begin{tabular}{lcclllll}
\hline & & $\begin{array}{l}\text { Hypo- } \\
\text { tension }\end{array}$ & $\begin{array}{l}\text { Brady- } \\
\text { cardia }\end{array}$ & $\begin{array}{l}\text { Nauseal } \\
\text { vomiting }\end{array}$ & Pruritus & $\begin{array}{l}\text { Respiratory Drow- } \\
\text { depression }\end{array}$ \\
siness
\end{tabular}

$* P<0.05$.

$\dagger P<0.01$.

TABLE III Postoperative meperidine requirement in $72 \mathrm{hr}$

\begin{tabular}{llrl}
\hline Group & $\begin{array}{l}\text { Maximum } \\
\text { dose }\end{array}$ & $\begin{array}{l}\text { Minimum } \\
\text { dose }\end{array}$ & $\begin{array}{l}\text { Average } \\
\text { dose } \pm S D\end{array}$ \\
\hline $\begin{array}{l}\text { Meperidine } \\
\text { Lidocaine }\end{array}$ & $\begin{array}{l}250 \mathrm{mg}(n=2) \\
500 \mathrm{mg}(n=10)\end{array}$ & $\begin{aligned} 000 \mathrm{mg}(n=4) \\
\mathrm{mg}(n=2)\end{aligned}$ & $\begin{array}{l}200 \mathrm{mg} \pm 36.5 \\
450 \mathrm{mg} \pm 12.5^{*}\end{array}$ \\
\hline
\end{tabular}

$* P<0.01$.

were drowsy $(P<0.01)$. Bradycardia and clinically observable respiratory depression $\left(<10\right.$ breaths $\left.\cdot \mathrm{min}^{-1}\right)$ were not detected in either group. The incidence of nausea and vomiting was the same (two patients each group) in both groups. However, all patients in the meperidine group received preoperative metoclopramide iv. No patient suffered from post-spinal headache or any neurological deficits.

\section{Postoperative analgesia}

Postoperative analgesic requirement over the first $72 \mathrm{hr}$ was less in the meperidine than in lidocaine group (Table III) $P<0.01$. The average duration of postoperative analgesia was six hours in the meperidine and one hour in the lidocaine group. Four patients in the meperidine group did not require any analgesic during the first 72 hr. Also, the patients in the meperidine group were found to ambulate more comfortably in the postoperative ward, as reported by postoperative staff.

\section{Discussion}

Intrathecal meperidine has been used by several investigators for a variety of surgical procedures. They all found it to be effective with only minor treatable side effects such as hypotension, pruritus, urinary retention, nausea and vomiting. There have been no reports, including the present study, of delayed respiratory depression with this agent, although early respiratory depression has been reported following epidural meperidine. ${ }^{2}$ The reason is thought to be due to its higher lipophilicity ${ }^{2}$ and the relative hyperbaricity of the $5 \%$ solution. ${ }^{3}$ The baricity of meperidine $5 \%$ has been reported to be either $1.009,{ }^{3}$ or 1.0086 at room temperature or even hypobaric. ${ }^{4}$ The specific gravity of our meperidine $5 \%$ (Roche UK), measured using a urinary-specific gravity meter was 1.026, which is higher than that of CSF (range
1.003-1.009). Unlike other investigators ${ }^{1}$ who added $10 \%$ dextrose, we added nothing to the meperidine solution. In the present study, increasing the degree of Trendelenburg position always increased the height of sensory blockade, which suggests that meperidine $5 \%$ behaves as an hyperbaric agent.

The final sensory level achieved with heavy lidocaine $5 \%$ was approximately two segments higher than with meperidine, which was also found by Patel et al. ${ }^{5}$ However, the level of sensory blockade was adequate for Caesarean section for most patients except for two in each group who were apprehensive, and required sedation at the time of skin incision. The motor blockade was much more intense in the lidocaine than in the meperidine group as assessed by Bromage score. ${ }^{7}$ Nevertheless, it was adequate in both groups to perform surgery without difficulty.

Although the blocks were performed just a few minutes before the delivery of the fetus and meperidine readily crosses the placenta, none of the newborns was depressed at the time of delivery. Resorption into the capillaries of the spinal cord is very slow, and a highly lipid soluble drug like meperidine is readily absorbed by lipid tissues. ${ }^{3}$ This may not be the only cause for the development of anaesthetic blockade following intrathecal meperidine, but it could be the reason why the maternal and hence the newborn's blood concentrations were not sufficient to cause respiratory depression. There have been no reports of compromised fetal outcome following the use of intrathecal meperidine for Caesarean section' ${ }^{1}$ as for painless delivery. ${ }^{4}$ In the latter report the baby did not present any problems despite an umbilical artery meperidine concentration level of $0.2 \mathrm{mg} \cdot \mathrm{L}^{-1}$.

There was a higher incidence of hypotension in mothers in the lidocaine $(n=15)$ than in the meperidine group $(n=8)$ perhaps because of the higher blockade that occurred in the lidocaine group. The incidence of nausea and vomiting may have been higher in meperidine group if the patients had not been given metoclopramide preoperatively. This was done to reduce the discomfort that follows repetitive retching and vomiting in a conscious subject. Pruritus occurred in eight patients (32\%) in the meperidine group, although it did not require treatment and disappeared spontaneously during the course of 
surgery. Drowsiness occurred in all patients in the meperidine group, but they were all readily arousable and cooperative. This may be an additional benefit of intrathecal meperidine because five patients from the lidocaine group required intraoperative sedation after delivery as they were quite nervous. Except for two patients who required sedation at the time of skin incision, no patients in the meperidine group required intraoperative sedation.

Postoperative analgesia was longer in the meperidine than in the lidocaine group (six hours vs one hour), and four patients did not require any analgesia postoperatively. The exact mechanism for such a prolonged analgesic effect is not known, although it has been suggested that it is due to an effect on the nociceptive synaptic junctions in the dorsal horn of the spinal cord. ${ }^{6}$ Whatever the mechanism, this effect of intrathecal meperidine is an added advantage over local anaesthetics.

In conclusion, intrathecal meperidine in a dose of 1 $\mathrm{mg} \cdot \mathrm{kg}^{-1}$ is superior to $5 \%$ heavy lidocaine, because of the prolonged postoperative analgesia. The side effects are also readily treatable. The commercial $5 \%$ solution is hyperbaric, and can be used for this purpose without addition of $10 \%$ glucose.

\section{Acknowledgements}

I wish to thank Drs. S.M. Dali and Bhola Rijal, obstetricians, for their cooperation during this study; all my junior colleagues who helped with intraoperative documentation and postoperative follow up; Prof. J.R. Maltby, and Prof. W.A. Tweed for their valuable advice during the preparation of this article; Mr. C.K. Gurung for statistical analysis and Mr. Rabindra Gautam, and Kumar Baral for word-processing.

\section{References}

1 Cheun $J K$, Kim $A R$. Intrathetcal meperidine as the sole agent for Cesarean section. J Korean Med Sci 1989; 4: 135-8.

2 Rosaeg OP, Suderman V, Yarnell RW. Early respiratory depression during Caesarean section following epidural meperidine. Can J Anaesth 1992; 39: 71-4.

3 Acalovschi I, Ene $V$, Lorinczi E, Nicolaus $F$. Saddle block with pethidine for perineal operations. Br J Anaesth 1986; 58: 1012-6.

4 Johnson MD, Hurley RJ, Gilbertson LI, Datta S. Continuous microcatheter spinal anesthesia with subarachnoid meperidine for labor and delivery. Anesth Analg 1990; 70: 658-61.

5 Patel D, Janardhan Y, Merai B, Robalino J, Shevde K. Comparison of intrathecal meperidine and licoaine in endoscopic urological procedures. Can J Anaesth 1990; 37: 567-70.

6 Glynn CJ, Mather LE, Cousins MJ, Graham JR, Wilson $P R$. Peridural meperidine in humans: analgesic responses, pharmacokinetics, and transmission into CSF. Anesthesiology 1981; 55: 520-6.

7 Bromage PR. A comparison of hydrochloride and carbon dioxide salts of lidocaine and prilocaine in epidural analgesia. Acta Anaesthesiol Scand 1965 (Suppl. 16), 55-69. 